УДК 338.43

DOI: 10.18101/2304-4446-2019-4-89-94

\title{
О МЕРАХ СОВЕРШЕНСТВОВАНИЯ СИСТЕМЫ ОБРАЗОВАНИЯ АГРАРНОГО ПРОФИЛЯ
}

\section{(C) Цыренов Даши Дашанимаевич}

Бурятский государственный университет имени Доржи Банзарова

Россия, 670000, г. Улан-Удэ, ул. Смолина, 24а

E-mail: dashi555@mail.ru

Аграрное образование выступает ключевым элементом инфраструктуры сельского хозяйства, так как именно оно обеспечивает кадрами потребность в трудовых ресурcax. От его состояния зависит не только настоящее, но и будущее агропрома каждого региона в отдельности, что в конечном итоге повышает продовольственную безопасность. В статье проанализировано состояние аграрного образования в Республике Бурятия, выявлены основные причины ухудшающегося его положения. Качество как абитуриентов, так и выпускников учреждений высшего и среднего профессионального образования подтверждает гипотезу о малой привлекательности сельского хозяйства как будущего объекта приложения труда молодежи. В статье предложен ряд организационных мер, внедрение которых не требует значительных финансовых вливаний, но реализация которых позволит повысить качество аграрного образования по всей вертикали - от средних школ до ссузов и вузов республики.

Ключевые слова: сельское хозяйство; аграрное образование; сельские территории; инфраструктура сельского хозяйства; системы образования.

\section{Для цитирования}

Цыренов Д. Д. О мерах совершенствования системы образования аграрного профиля // Вестник Бурятского государственного университета. Экономика и менеджмент. 2019. № 4. С. 89-94.

Развитие аграрного производства является базовым основанием обеспечения жизнедеятельности населения. Именно сельскохозяйственное и связанное с ним производство продуктов питания обеспечивает продовольственную безопасность региона. Ключевым фактором развития сельского хозяйства выступает его инфраструктура, важную роль в которой играет система образования.

Подготовка кадров аграрного профиля в Республике Бурятия осуществляется преимущественного в учебных заведениях высшего и среднего профессионального образования республики (табл. 1).

Таблица 1

Контрольные цифры приема абитуриентов на образовательные программы аграрного профиля в Республике Бурятия в 2019 г.

\begin{tabular}{|c|c|c|c|c|c|}
\hline \multirow[t]{2}{*}{ № } & \multirow[t]{2}{*}{$\begin{array}{c}\text { Наименование } \\
\text { учебного заведения }\end{array}$} & \multirow{2}{*}{$\begin{array}{c}\text { Наименование } \\
\text { образовательной } \\
\text { программы }\end{array}$} & \multicolumn{3}{|c|}{$\begin{array}{c}\text { Контрольные цифры приема } \\
\text { по уровням образования }\end{array}$} \\
\hline & & & спо & Бакалавриат & Магистратура \\
\hline \multirow[t]{3}{*}{1} & \multirow{3}{*}{$\begin{array}{l}\text { Бурятская государ- } \\
\text { ственная сельскохозяй- } \\
\text { ственная академия им. }\end{array}$} & Агроинженерия & & 110 & 28 \\
\hline & & Агрономия & & 35 & 21 \\
\hline & & Агрохимия и агропочво- & & 25 & 10 \\
\hline
\end{tabular}


ВЕСТНИК БУРЯТСКОГО ГОСУДАРСТВЕННОГО УНИВЕРСИТЕТА.

\begin{tabular}{|c|c|c|c|c|c|}
\hline & В. Р. Филиппова & ведение & & & \\
\hline & & Биология & & 15 & \\
\hline & & $\begin{array}{l}\text { Ветеринарно-санитарная } \\
\text { экспертиза }\end{array}$ & & 35 & \\
\hline & & Ветеринария & & 80 & \\
\hline & & $\begin{array}{l}\text { Водные ресурсы и } \\
\text { аквакультура }\end{array}$ & & 30 & \\
\hline & & $\begin{array}{l}\text { Геодезия и } \\
\text { дистанционное } \\
\text { зондирование }\end{array}$ & & 12 & \\
\hline & & $\begin{array}{l}\text { Землеустройство и } \\
\text { кадастры }\end{array}$ & & 41 & 10 \\
\hline & & Зоотехния & & 50 & 40 \\
\hline & & Лесное дело & & 40 & 18 \\
\hline & & $\begin{array}{l}\text { Природоустройство и } \\
\text { водопользование }\end{array}$ & & 10 & 10 \\
\hline & & Садоводство & & 25 & \\
\hline & & $\begin{array}{l}\text { Технология производ- } \\
\text { ства и переработки } \\
\text { сельскохозяйственной } \\
\text { продукции }\end{array}$ & & 35 & \\
\hline & & Всего по БГСХА & & 543 & 137 \\
\hline 2 & Бурятский государ- & Биология & & 25 & 11 \\
\hline & $\begin{array}{l}\text { ственный университет } \\
\text { имени Доржи Банзаро- }\end{array}$ & $\begin{array}{l}\text { Землеустройство и } \\
\text { кадастры }\end{array}$ & & 15 & 13 \\
\hline & ва & Всего по БГУ & & 40 & 24 \\
\hline 3 & $\begin{array}{l}\text { Восточно-Сибирский } \\
\text { государственный уни- }\end{array}$ & $\begin{array}{l}\text { Прибороустройство и } \\
\text { водопользование }\end{array}$ & & 10 & \\
\hline & верситет технологий и & Агроинженерия & & 15 & \\
\hline & управления & $\begin{array}{l}\text { Биотехнические системы } \\
\text { и технологии }\end{array}$ & & 17 & \\
\hline & & Биотехнология & & 10 & \\
\hline & & $\begin{array}{l}\text { Продукты питания } \\
\text { животного } \\
\text { происхождения }\end{array}$ & & 16 & 10 \\
\hline & & $\begin{array}{l}\text { Продукты питания из } \\
\text { растительного сырья }\end{array}$ & & 10 & \\
\hline & & $\begin{array}{l}\text { Эксплуатация транс- } \\
\text { портно-технологических } \\
\text { машин и комплексов }\end{array}$ & & 10 & \\
\hline & & Всего по ВСГУТУ & & 88 & 10 \\
\hline 4 & Бурятский аграрный & Землеустройство & 25 & & \\
\hline & $\begin{array}{l}\text { колледж им. М. Н. Ер- } \\
\text { банова }\end{array}$ & $\begin{array}{l}\text { Управляющий сельской } \\
\text { усадьбой }\end{array}$ & 25 & & \\
\hline & & Агрономия & 25 & & \\
\hline & & $\begin{array}{l}\text { Механизация сельского } \\
\text { хозяйства }\end{array}$ & 25 & & \\
\hline & & Ветеринария & 50 & & \\
\hline 5 & $\begin{array}{l}\text { Бурятский } \\
\text { лесопромышленный } \\
\text { колледж }\end{array}$ & $\begin{array}{l}\text { Садово-парковое и } \\
\text { ландшафтное строи- } \\
\text { тельство }\end{array}$ & 25 & & \\
\hline & & Механизация сельского & 25 & & \\
\hline
\end{tabular}




\begin{tabular}{|c|c|c|c|c|c|}
\hline & & хозяйства & & & \\
\hline & & $\begin{array}{l}\text { Тракторист-машинист } \\
\text { сельскохозяйственного } \\
\text { производства }\end{array}$ & 25 & & \\
\hline \multirow[t]{2}{*}{6} & \multirow[t]{2}{*}{$\begin{array}{l}\text { Закаменский } \\
\text { агропромышленный } \\
\text { техникум }\end{array}$} & $\begin{array}{l}\text { Мастер } \\
\text { сельскохозяйственного } \\
\text { производства }\end{array}$ & 25 & & \\
\hline & & $\begin{array}{l}\text { Тракторист-машинист } \\
\text { сельскохозяйственного } \\
\text { производства }\end{array}$ & 10 & & \\
\hline 7 & $\begin{array}{l}\text { Джидинский } \\
\text { многопрофильный } \\
\text { техникум } \\
\end{array}$ & $\begin{array}{l}\text { Тракторист-машинист } \\
\text { сельскохозяйственного } \\
\text { производства } \\
\end{array}$ & 0 & & \\
\hline \multirow[t]{2}{*}{8} & $\begin{array}{l}\text { Колледж традиционных } \\
\text { искусств народов За- } \\
\text { байкалья }\end{array}$ & $\begin{array}{l}\text { Механизация сельского } \\
\text { хозяйства }\end{array}$ & 25 & & \\
\hline & $\begin{array}{l}\text { ИТОГО по учебным } \\
\text { заведениям РБ }\end{array}$ & & 285 & 671 & 171 \\
\hline
\end{tabular}

В летнюю приемную кампанию 2019/20 учебного года в Республике Бурятия прием абитуриентов на образовательные программы аграрного профиля осуществлялся в 3 вузах и 5 учебных заведениях среднего профессионального образования. В общей сложности было выделено за счет средств федерального бюджета 671 место на программы бакалавриата и 171 место на программы магистратуры, а также 285 мест на программы СПО за счет республиканского бюджета. Наибольшую долю на рынке образовательных услуг занимает профильный вуз - Бурятская государственная сельскохозяйственная академия им. В. Р. Филиппова Министерства сельского хозяйства РФ - более $80 \%$ бакалавриата и магистратуры.

Основная проблема современного образования в РФ - снижение среднего качества выпускников по вертикали образования - начиная с общеобразовательных учреждений и завершая высшей школой. Ключевым параметром оценки качества образования на школьном уровне, который применяется на протяжении более 10 лет, выступает единый государственный экзамен (ЕГЭ). Так, по итогам мониторинга вузов России в 2018 г. отраслевой аграрный вуз республики БГСХА им. В. Р. Филиппова - набирает лишь 51,7 балла при пороговом значении, определенном в 60 баллов. Иными словами, качество абитуриентов, выбравших БГСХА, в среднем ниже на 8,3 балла.

Критерием оценки деятельности учебных заведений является начало трудовой карьеры выпускников по профилю полученного высшего образования, количественным выражением которого выступает доля трудоустроившихся на основе полученного диплома о высшем образовании. По результатам того же ежегодного мониторинга в республике наблюдается нежелание подавляющей части выпускников, имеющих аграрное образование, начать профессиональную деятельность в соответствии с полученным образованием. Так, для выпускников БГСХА данный показатель составил $40 \%$ при нижнем рекомендованном значении $70 \%$. Ситуация по выпускникам учреждений СПО выглядит не лучше.

$\mathrm{B}$ основе негативно сложившейся ситуации (проблемы на входе и выходе из профильного аграрного образования) лежит мнение абитуриентов и их родителей 
о непрестижности объекта будущего приложения труда. Архаичность и ригидность аграрной сферы в целом приводит к падению количественных и качественных показателей спроса на профильное образование со стороны населения.

Выход из ситуации на общесистемном федеральном уровне видится в активном внедрении цифровых, биологических, «зеленых» технологий в сельское хозяйство, что в целом повысит привлекательность для абитуриентов.

В конкретном регионе, например в Республике Бурятия, следует предпринять ряд мер и действий по совершенствованию системы образования аграрного профиля. Первоочередные меры в разбивке по уровням образования представлены в таблице 2 .

Таблица 2

Ключевые направления совершенствования аграрного образования в Республике Бурятия

\begin{tabular}{|c|c|}
\hline Уровень образования & Направления совершенствования \\
\hline Общее среднее & $\begin{array}{l}\text { 1. Возобновление практики трудового обучения и воспитания в шко- } \\
\text { лах республики. } \\
\text { 2. Восстановление деятельности пришкольных участков для прове- } \\
\text { дения опытно-экспериментальных работ. } \\
\text { 3. Учреждение сети малых инновационных предприятий (МИПов) в } \\
\text { школах, ориентированных на осуществление разведения лекар- } \\
\text { ственных растений с последующим сбором, переработкой и реали- } \\
\text { зацией готовой продукции. } \\
\text { 4. Открытие естественнонаучного и агробиологического профилей в } \\
\text { учреждениях детского отдыха. } \\
\text { 5. Формирование системы ранней профориентации учащихся путем } \\
\text { краткосрочных стажировок в период сезонных каникул учащихся в } \\
\text { организациях различной организационно-правовой формы. } \\
\text { 6. Организация сети классов аграрного профиля в сельских муници- } \\
\text { пальных районах с целью подготовки заинтересованных абитуриен- } \\
\text { тов. } \\
\text { 7. Налаживание научного кураторства отдельных школ республики } \\
\text { для проведения научно-исследовательской работы аграрного про- } \\
\text { филя. } \\
\text { 8. Выделение в системе действующих олимпиад, конференций, се- } \\
\text { минаров учащихся мероприятий, связанных с аграрным профилем. }\end{array}$ \\
\hline $\begin{array}{l}\text { Среднее } \\
\text { профессиональное и } \\
\text { высшее }\end{array}$ & $\begin{array}{l}\text { 1. Организация форсайт-сессии с участием экспертов и других заин- } \\
\text { тересованных сторон для выявления стратегических ориентиров } \\
\text { развития системы образования аграрного профиля. } \\
\text { 2. Внедрение системы профессиональных стандартов при подготов- } \\
\text { ке на программах высшего образования. } \\
\text { 3. Лицензирование и последующая аккредитация новых образова- } \\
\text { тельных программ под нужды агропрома республики. } \\
\text { 4. Формирование сети базовых кафедр крупнейших предприятий по } \\
\text { производству и переработке сельскохозяйственной продукции. } \\
\text { 5. Перевод действующей системы оценки подготовленности выпуск- } \\
\text { ников на оценку сформированности компетенций по стандартам } \\
\text { WorldSkills. } \\
\text { 6. Учреждение в учебных заведениях республики бизнес- } \\
\text { инкубаторов, имеющих аграрную специализацию, либо организация }\end{array}$ \\
\hline
\end{tabular}




\begin{tabular}{|c|c|}
\hline & $\begin{array}{l}\text { единого республиканского аграрного бизнес-инкубатора. } \\
\text { 7. Перенятие опыта по целевой подготовке специалистов с аграрным } \\
\text { образованием для последующей трудовой деятельности на условия } \\
\text { механизма обязательного распределения. } \\
\text { 8. Учреждение премии или именной стипендии крупных сельскохо- } \\
\text { зяйственных предприятий, а также Министерства сельского хозяй- } \\
\text { ства и продовольствия республики. } \\
\text { 9. Расширение направлений деятельности действующего Промпарка } \\
\text { республики с привлечением исследователей из вузовской, академи- } \\
\text { ческой и отраслевой науки. } \\
\text { 10. Проработка механизмов и инструментов мотивации сельхозто- } \\
\text { варопроизвителей для опытного внедрения и промышленной экс- } \\
\text { плуатации результатов научно-исследовательской работы учрежде- } \\
\text { ний науки и образования республики. } \\
\text { 11. Формирование базы знаний, включающей информацию о завер- } \\
\text { шенных НиР, готовых к внедрению. } \\
\text { 12. Организация подгтовки специалистов аграрного профиля по } \\
\text { всей сети колледжей и техникумов республики, включая их филиалы } \\
\text { в сельских муниципальных образованиях. } \\
\text { 13. Возобновление деятельности диссертационных советов по вете- } \\
\text { ринарным и сельскохозяйственным наукам, учрежденных при БГСХА } \\
\text { им. В. Р. Филиппова }\end{array}$ \\
\hline $\begin{array}{l}\text { Дополнительное образо- } \\
\text { вание детей и взрослых }\end{array}$ & $\begin{array}{l}\text { 1. Популяризация актуальных знаний среди сельского населения по } \\
\text { вопросам органического земледелия, традиционных и инновацион- } \\
\text { ных форм организации сельского хозяйства. } \\
\text { 2. Обучение безработных граждан, лиц предпенсионного возраста, } \\
\text { женщин в декретном отпуске по уходу за детьми по линии Респуб- } \\
\text { ликанского агентства занятости населения по программе «Аграрное } \\
\text { предпринимательство». } \\
\text { 3. Формирование информационной площадки для организации он- } \\
\text { лайн и оффлайн обучения заинтересованных сельских жителей ос- } \\
\text { новам сельскохозяйственного производства и предпринимательства. } \\
\text { 4. Формирование системы консультационной поддержки на местах } \\
\text { сельского населения по вопросам организации высокопродуктивно- } \\
\text { го личного подсобного хозяйства }\end{array}$ \\
\hline
\end{tabular}

Реализация предлагаемых действий позволит системе образования стать локомотивом в дальнейшем развитии агропрома Республики Бурятия.

\section{Литература}

1. Атанов Н. И., Намханова М. В., Цыренов Д. Д. Байкальский субрегион: проблемы внутренней кооперации и пути их решения // Современные технологии управления. 2015. № 5(53). C. 2-10.

2. Золотарева Н. А., Ванчикова Е. Н., Архипов С. В. Факторы и мотивы выбора образовательного учреждения в системе высшего образования (на примере Республики Бурятия) // Вестник Забайкальского государственного университета. 2019. Т. 25, № 1. С. $86-$ 92.

3. Полянская Н. М. Социальное партнерство в образовательном процессе // Colloquium-journal. 2018. № 9-3(20). C. 56-59.

4. Слепнева Л. Р., Цыренов Д. Д. Совершенствование организационнохозяйственной инфраструктуры в сельском хозяйстве региона // Вестник Бурятского государственного университета. 2012. № S4. С. 33-37. 
5. Янтранов А. Е., Атанов Н. И., Архипов С. В. Университеты как институты регионального развития (на примере Республики Бурятия) // Вестник Бурятского государственного университета. Экономика и менеджмент. 2019. № 1. С. 62-67.

\section{ON MEASURES AIMED AT IMPROVEMENT OF THE SYSTEM OF AGRICULTURAL EDUCATION}

Dashi D. Tsyrenov

Dorzhi Banzarov Buryat State University

24a Smolina St., Ulan-Ude 670000, Russia

E-mail: dashi555@mail.ru

Professional education is a key element of agricultural infrastructure, since it provides the sector with labor resources. Not only the present, but also the future state of agricultural industry of each region depends on the educational status, which in turn influences the food security. The article analyzes the status of agricultural education in the Republic of Buryatia, identifies the main reasons for deteriorating situation in this field. The quality of both applicants and graduates of the institutions of higher and secondary vocational education confirms the hypothesis of the low attractiveness of agriculture as a future object of youth labor. We have proposed a number of organizational measures, which implementation does not require significant financial injections, but will improve the quality of agricultural education in secondary schools, colleges and universities of the republic.

Keywords: agriculture; agricultural education; rural areas; agricultural infrastructure; education systems. 